\title{
Comparing the ISBA and J2000 approaches for surface flows modelling at the local scale in the Everest region
}

\author{
Judith Eeckman ${ }^{\mathrm{a}}$, Santosh Nepal ${ }^{\mathrm{b}}$, Pierre Chevallier ${ }^{\mathrm{a}}$, Gauthier Camensuli ${ }^{\mathrm{a}}$, Francois \\ Delclaux $^{\mathrm{a}}$, Aaron Boone ${ }^{\mathrm{c}}$, Anneke De Rouw ${ }^{\mathrm{d}}$ \\ ${ }^{a}$ Laboratoire HydroSciences (CNRS, IRD, Universite de Montpellier) CC 57 - Universite de Montpellier \\ 163, rue Auguste Broussonnet 34090 Montpellier, France; \\ ${ }^{b}$ International Centre for Integrated Mountain Development (ICIMOD), GPO Box 3226, Kathmandu, \\ Nepal; \\ ${ }^{c}$ CNRM UMR 3589, Meteo-France/CNRS, Toulouse, France; \\ ${ }^{d}$ Institut d'Ecologie et des Sciences d'Environnement de Paris (IRD, UPMC), 4place Jussieu, 75252 Paris \\ cedex 5, France.
}

\begin{abstract}
This paper compares the hydrological responses at the local scale of two models using different degrees of refinement to represent physical processes in sparsely instrumented mountainous Himalayan catchments. This work presents the novelty of applying, at a small spatiotemporal scale and under the same forcing conditions, a fully distributed surface scheme based on mass and energy balance equations (ISBA surface scheme), and a semi-distributed calibrated model (J2000 hydrological model). A new conceptual module coupled to the ISBA surface scheme for flow routing is presented. Two small catchments located in midand high- mountain environments were chosen to represent the very different climatic and physiographic characteristics of the Central Himalayas in the Everest region of eastern Nepal. The results show that both models globally represent the dynamic of the processes for evaporation, quick runoff and discharge in a similar way. The differences in the model structures and results mainly concern the snow processes and the soil processes. In particular for the high-mountain catchment, the snow-pack simulation is shown to be the main driver of the discrepancy between the two models. The sub-daily variations of snow processes are shown to significanlty influence the estimation of the snow-melt contribution to discharge.

Keywords: Central Himalayas, ISBA surface scheme, J2000 model, water budget at the local scale, structural uncertainty;
\end{abstract}




\section{Introduction}

2

Modelling hydro-climatic systems for a Himalayan catchments is particularly challenging because of the double-edged situation of highly heterogeneous and sparsely instrumented catchments. On the one hand, sharp topographic variations in this region result in extreme climatic heterogeneities (Barros et al., 2004; Anders et al., 2006) and on the other hand, the high-altitude areas have limited hydro-meterological monitoring devices. A combination of these issues critically limits the representation of hydrological responses at regional scales in the Himalayan region.

The central part of the Hindu Kush Himalaya region ranges from the Terai agricultural plain in the South to the highest peaks in the world to the north (FIGURE 1). The two main driving climatic processes are the summer Indian monsoon, which contributes approximately $80 \%$ of the total annual precipitation over the central Himalayan range (Bookhagen and Burbank, 2006; Dhar and Rakhecha, 1981), and winter precipitation arising from westerlies (Lang and Barros, 2004).

Limited access and physical constraints stemming from the region's steep topography explain that the density of meteorological stations is particularly low in the Himalayan region. Recorded time series are more often short in duration and associated with significant uncertainties (Salerno et al., 2015). Moreover, most of the stations are located in river valleys, which may not represent the spatial variation of precipitation in nearby mountain ranges. The gridded climate products from regional and global data sets provide a good deal of uncertainty due to interpolation approaches and a trade-off between resolution and availability of observed data (Li et al., 2017).

Various hydrological modelling approaches have been set up for several basins of the central Himalayas, at different spatio-temporal scales, from physically-oriented representations of processes, such as TOKAPI by Pellicciotti et al. (2012) or SWAT by Bharati et al. (2016), to more conceptual ones, such as SRM by Immerzeel et al. (2010), GR4J by Andermann et al. (2012) and Pokhrel et al. (2014), GR4JSG by Nepal et al. (2017a), SPHY by Lutz 
et al. (2014), HDSM by Savéan et al. (2015) and J2000 by Nepal et al. (2014, 2017b). However, large discrepancies remain in the representation of hydrological processes among several studies at a regional scale stemming from the variation in modelling applications, input data and the processes taken into account.

For instance, for the Dudh Koshi River basin, annual actual evapotranspiration is estimated at 14\%, 20\% and 52\%, respectively, of annual precipitation by Andermann et al. (2012); Nepal et al. (2014) and Savéan et al. (2015). Estimations of the snow melt contribution to annual stream flow at the outlet of the Dudh Koshi River basin range from $6 \%$ (Andermann et al., 2012) to 27\% (Nepal et al., 2014); estimations of the glaciar melt contribution to annual stream flow range from 4\% (Andermann et al., 2012) to 19\% (Lutz et al., 2014). Moreover, estimations of the contribution of underground water to surface flow are still very divergent because of the variation in methodological approaches. The contribution of groundwater flows to annual stream flows is estimated at about $60 \%, 20 \%$ and $12 \%$, respectively, by Andermann et al. (2012); Nepal et al. (2014) and Lutz et al. (2014). The variation is mainly due to the conceptualization of groundwater processes in different models, for example J2000 represents two compartments for groundwater storage, whereas SPHY has one and GR4J has a conceptual representation of groundwater.

Taking into account this difficult context, the aim of this paper is to initiate a model inter-comparison work by comparing two approaches that have been previously applied to sparsely instrumented catchments in the Himalayas, namely the work of Eeckman (2017) that uses the ISBA (Interaction Sol-Biosphere-Atmosphere) surface and the work of Nepal et al. (2014) that uses the J2000 distributed hydrological model. The ISBA surface scheme (Noilhan and Planton, 1989; Noilhan and Mahfouf, 1996) allows to simulate the interaction between the hydrosphere, the biosphere and the atmosphere taking into account both the mass and the energy balance at the surface and its propagration into the soil. In this study, an additional conceptual module is coupled to ISBA to represent the flow routing, which was not originally included in the surface scheme. The J2000 model applies a process-based approach through calibration parameters and is distributed based on Hydrological Response 
Units (HRUs). The J2000 model has been applied in Himalayan catchments at meso-scale catchments such as the Dudh Koshi and and Tamor river basin (Nepal et al., 2017b).

Two small catchments were chosen to represent different climatic and physiographic characteristics of the Central Himalayas: the Kharikhola $\left(18.2 \mathrm{~km}^{2}\right)$ and the Tauche catchment $\left(4.6 \mathrm{~km}^{2}\right)$ which represent middle mountains and headwaters of high mountains respectively of the Nepalese Himalayas. Input uncertainties associated with both climatic variables and static spatial parametrization for topography, soil and vegetation were minimized as much as possible using data sets that have been locally validated based on in situ measurements of both meteorological variables and surface properties. The same data sets are used in both models, not only for the meteorological forcing but also for the soil and surface descriptions.

The novelty of the study is to apply in this sparsely intrumented region, at a small spatiotemporal scale and under the same forcing conditions, two models that deeply differs in their degrees of conceptualization: on the one side, a fully distributed surface scheme based on mass and energy balance equations and,d on the other side, a semi-distributed calibrated model.

\section{Study area}

The Kharikhola and Tauche sub-catchments are part of the Dudh Koshi River basin in Eastern Nepal. This basin has a steep topography and high mountain peaks including Mt Everest, (8848, m a.s.l), dominated by a sub-tropical climate in lower areas and an alpine climate in high-altitude areas (see FIGURE 1). These two sub-catchments present different climatic and physiographic characteristics.

The elevation of the Kharikhola catchment varies from from $1980 \mathrm{~m}$ a.s.l. to $4660 \mathrm{~m}$ a.s.l. with an area of $18.20 \mathrm{~km}^{2}$. This catchment is covered by extensive agricultural areas (below 2500 m.a.s.l), forests ( between 2500 m.a.s.l and 3500 m.a.s.l) and sparce vegetation areas (above 3500 m.a.s.l). The glaciar coverage on the Kharikhola catchment is nil. The elevation of the Tauche catchment varies from from $3980 \mathrm{~m}$ a.s.l. to $6110 \mathrm{~m}$ a.s.l. with an area of 4.6 
$90 \mathrm{~km}^{2}$. This catchment is sparsely vegetated, mainly covered by shrublands or alpine steppes.

91 On the Tauche catchment, the Tauche peak glacier is suspended upstream of the catchment

92 and accounts for about $0.37 \%$ of the basin's total area, according to Racoviteanu et al. (2013)

93 up-to-date glaciar inventory. The glacial contribution to the flow for the Tauche catchment is

94 therefore considered to be negligible and is not included in the modelling applications. The

95 main morphological characteristics of the two catchments studied are summarized in TABLE

961.

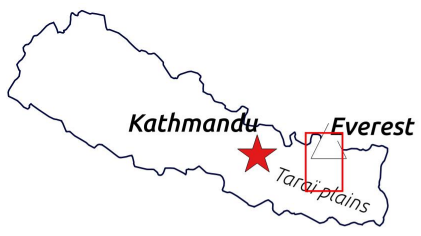

$D$
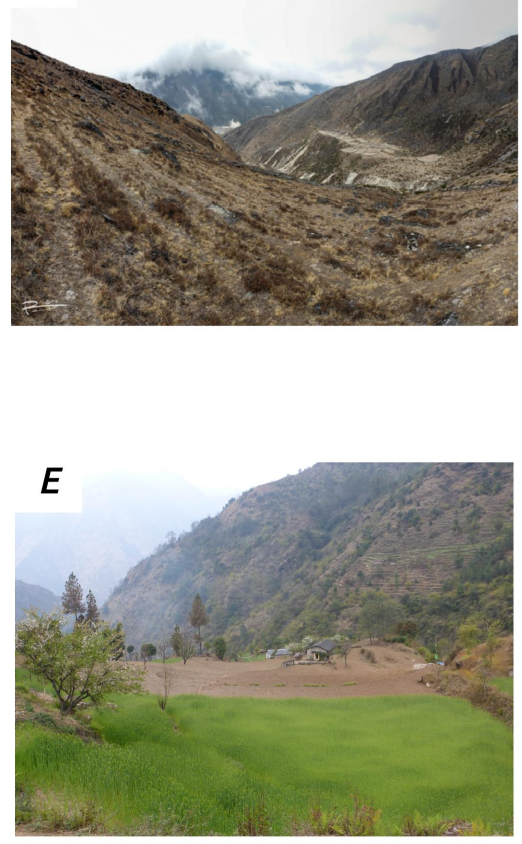
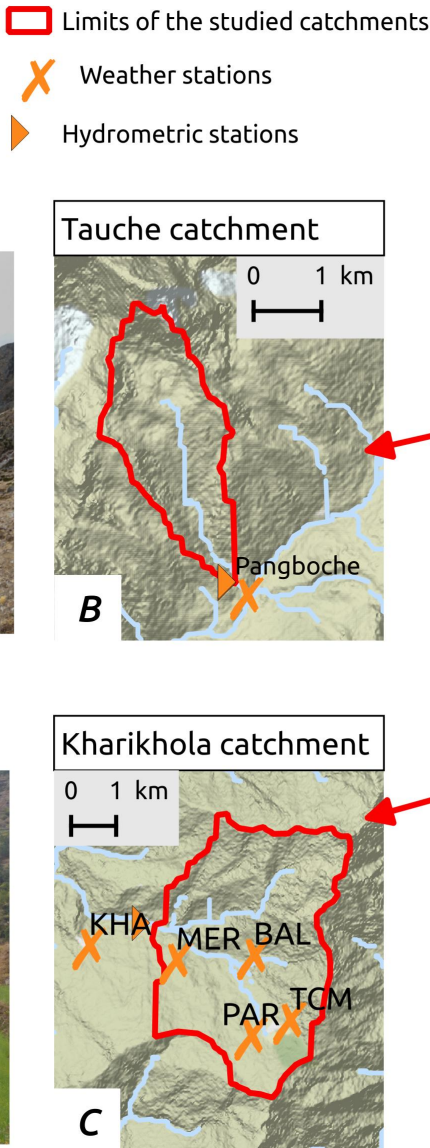

A

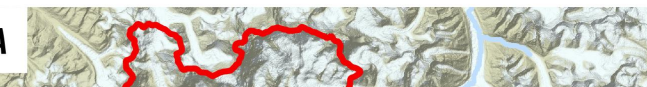

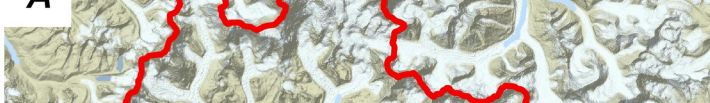

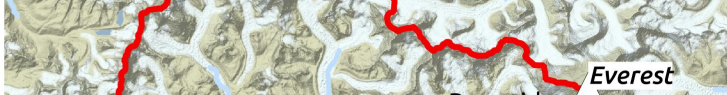
- 5 f a 20 Pyramid Everest

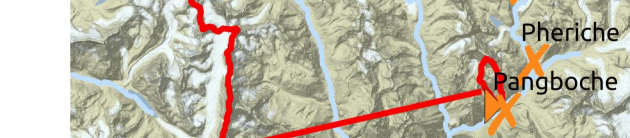
- 28 Namche -1 2 Phakding $2 \int_{3} \int^{\text {Lukla }}$

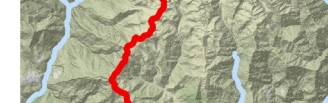

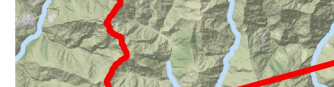
1. 5

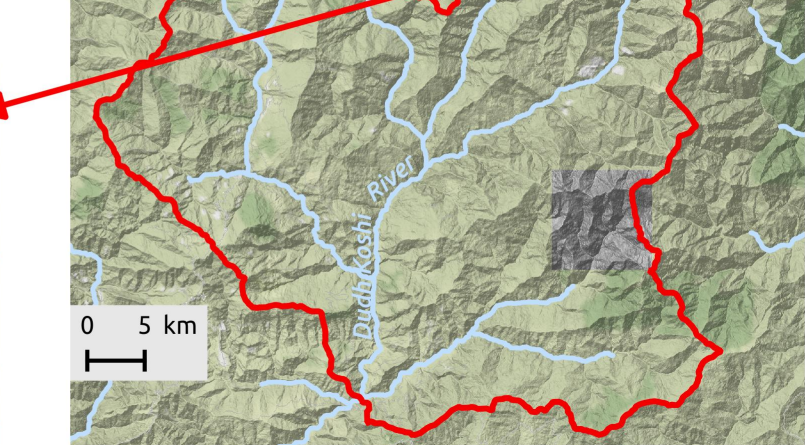

Figure 1: Map of the studied area: (A) the Dudh Koshi River basin at the Rabuwabazar gauging station, managed by the Department of Hydrology and Meteorology of the Nepal Government. The (B) Tauche and (C) Kharikhola sub-catchments are defined by the corresponding gauging stations. Source: OpenStreetMaps, photos by Rémi Muller (D) and Judith Eeckman (E). 
Table 1: Summary of the main morphological characteristics of the two catchments studied: : Kharikhola catchment and Tauche catchment (Nepal), which represents mid-altitude mountains and high-mountain headwaters, respectively.

\begin{tabular}{cccc} 
& Kharikhola & Tauche & unit \\
\hline Area & 18.2 & 4.6 & $\mathrm{~km}^{2}$ \\
Elevation range & $1980-4660$ & $3980-6110$ & m.a.s.l. \\
Glaciarized area & $0 \%$ & $0.37 \%$ & -
\end{tabular}

Discharge data from 2014-05-03 to 2016-05-20 from 2014-05-07 to 2016-05-09

\section{Modelling approaches}

The implementation choices are summarized for both models in TABLE 2.

\subsection{The ISBA surface scheme and the HDSM routing module}

The ISBA (Interaction Soil Biosphere Atmosphere) surface scheme (Noilhan and Planton, 1989; Noilhan and Mahfouf, 1996) is implemented in the SURFEX platform (Masson et al., 2013) to represent the nature land tile. The latest version 8 of SURFEX is used for this work. The ISBA surface scheme simulates vertical fluxes between the soil, vegetation and the atmosphere at a sub-hourly time step (SVAT model). Different implementations of soil transfers, vegetation, sub-grid hydrology and snow processes are available in SURFEX. Implementations of ISBA functions described in TABLE 2 are used in this study. The explicit multilayer version of ISBA (ISBA-DIF) uses a diffusive approach (Boone et al., 2000; Decharme et al., 2011): surface and soil water fluxes are propagated from the surface through the soil column. Transport equations for mass and energy are solved using a multilayer vertical discretization of the soil. The explicit snow scheme in ISBA (ISBA-ES) (Boone and Etchevers, 2001; Decharme et al., 2016) uses a twelve-layer vertical discretization of snow pack and provides a mass and energy balance for each layer. Snow-melt and snow sublimation are taken into account in balance equations.

The Dunnes flow (Dunne, 1983) and Hortons flow (Horton, 1933) are separately modelized in ISBA. The Dunnes flow is the saturation excess runoff i.e. the fraction of the precipitation that flows at the surface when the soil is saturated. The Hortons flow is the infiltration excess runoff i.e. the fraction of precipitation that flows at the surface when the intensity of the precipitation is greater than the soil capacity of infiltration. The Horton's and Dunne's flow mechanisms are modeled using a sub-grid parameterization described in Habets et al. (1999): The Dunne runoff for each grid cell depends on the fraction of the cell that is saturated. The 
Since the dependency between mesh cells is not initially implemented in the SURFEX platform, an additional routing module was implemented and coupled to ISBA offline simulations. This module is adapted from the HDSM (Hydrological Distributed Snow Model) model, and it has been implemented and used by Savéan et al. (2015) on the Dudh Koshi River bassin. The advantage of using the ISBA-HDSM coupling is to use both a non calibrated surface scheme for production function and a routing module that has been previously applied on the same area. The structure of the module is extensively described in Savéan (2014). For each cell, surface runoff (given by the sum of Dunne runoff and Horton runoff) and the drainage at the bottom of the soil column are directed toward two simple linear reservoirs, $R_{s}$ and $R_{d}$ respectively. Residence times in $R_{s}$ and $R_{d}$ (respectively, $t_{s}$ and $t_{d}$ ) are calibrated as uniform parameters over the catchment. The sum of the output flows of $R_{s}$ and $R_{d}$ is then directed toward the transfer reservoir, which allows propagating the flows according to terrain orography. The residence time in the transfer reservoir is defined for each mesh point as the ratio between the flow velocity and the distance from the centre of the mesh point to the centre of the previous upstream mesh point. The flow velocity is calculated as the ratio of the mesh point slope and a reference slope, taken equal to the catchment median slope. This ratio is weighted by a $c_{v e l}$ transfer coefficient. $c_{v e l}$ is calibrated as a uniform parameter. The main driving equations of this routing module and its calibration are reported in Appendix A. The code for this routing module is implemented in fortran90 language and available at www.papredata.org.

\subsection{J2000 modelling system}

The J2000 hydrological model is a process-oriented hydrological model (Krause, 2001). The model is implemented in the Jena Adaptable Modelling System (JAMS) framework 
(Kralisch and Krause, 2006; Kralisch et al., 2007), which is a software framework for componentbased development and application of environmental models. The J2000 model includes the main hydrological processes of high-mountain catchments. A short description of the main processes has been provided in TABLE 2. A more detailed description is provided by Krause (2001) and Nepal (2012). The J2000 model has already been applied to Himalayan catchments (Nepal et al., 2014, 2017a).

To optimize the J2000 model parameters for the KhariKhola and Tauche catchments, we used the base parameter set from a previous study by (Nepal et al., 2014), which was defined for the Dudh Koshi River basin at the Rabuwabazaar gauging station $\left(3712 \mathrm{~km}^{2}\right)$. Similarly, (Nepal et al., 2017a) also used the same parameter sets for nearby Tamor subcatchment $\left(4005 \mathrm{~km}^{2}\right)$ to argue that spatial transferability of the J2000 model parameters is possible in neighbouring catchments with physical and climatic similarities. Out of 30 parameters, six parameters were optimized further to match the catchment responses in the KhariKhola and Tauche catchments: the groundwater recession coefficient for baseflow (gwRG2Fact), the coefficient for the distribution of water between the upper and lower zone of groundwater (gwRG1RG2dist), the recession coefficient for RD1 and RD2 (soilConcRD1 and soilConcRD2), maximum percolation (soilMaxPerc) and snowmelt threshold (baseTemp) and the parameter to distribute precipitation into rainfall and snow (trs). The recession coefficient for floods from (Nepal et al., 2014) is not applied here because of the local scale catchments. Because of the basin size and climatic variability within the catchment and related scale issues, optimization of parameters is suggested. The description of these parameters along with their dimensions are available in Nepal et al. (2017a).

\subsection{Spatial discretization methods}

The SPOT DEM (Gardelle et al., 2012), as well as soil and land cover maps are provided for both catchments at the 40-m resolution. In ISBA, the catchments are discretized over a regular grid at the 400-m resolution. Sixty-nine grid cells are defined for the Kharikhola catchment and 28 grid cells are defined for the Tauche catchment. In J2000, the catchments are discretized into 346 and 132 HRUs, respectively. The minimum size of HRUs is forced to be larger than 5 DEM pixels, i.e. $0.008 \mathrm{~km}^{2}$. TABLE 3 summarizes the results of the spatial discretization for both modelling applications. FIGURE 2 shows the hypsometric 
information of the land surface area in different elevation zones. Although the overall pattern of hypsometry is similar in both models, they tend to show fairly opposite area coverage above and below about 3000 m.a.s.l. for Kharekhola and 5000 m.a.s.l. for Tauche.
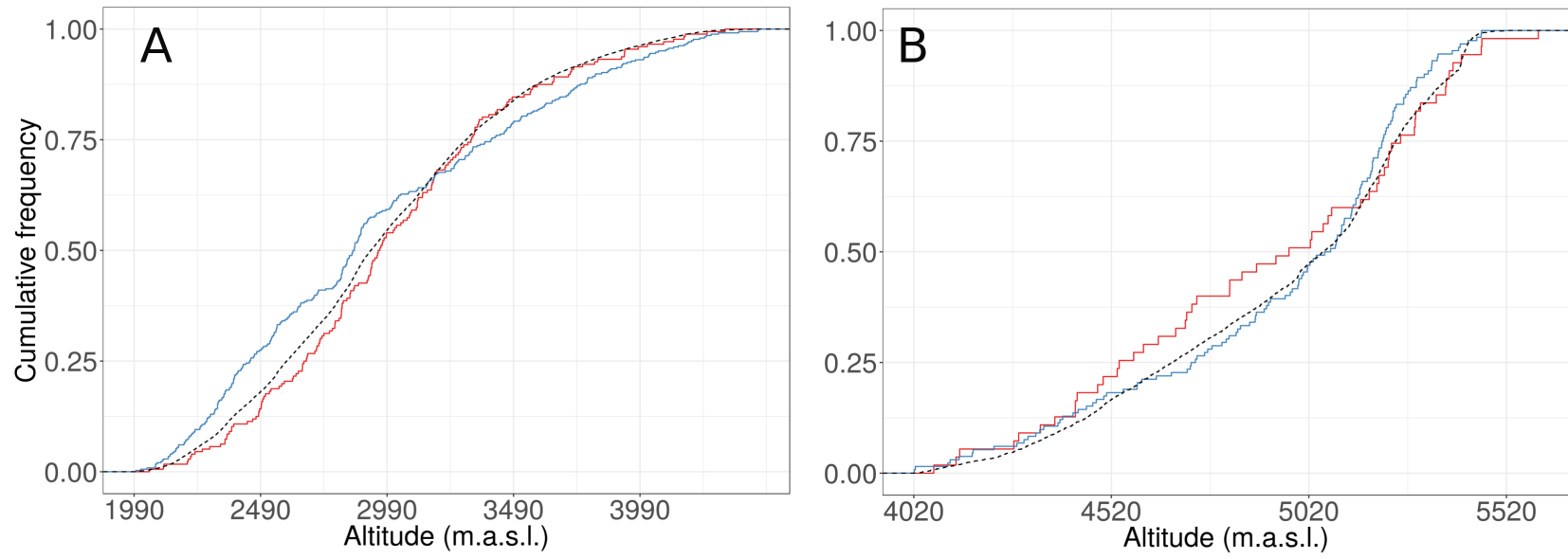

Figure 2: Hypsometric curve for Kharikhola catchment (A) and for the Tauche catchment (B), provided by the IBSA discretization on a regular grid at the 400-m resolution (red curve) and by the J2000 discretization into HRUs (blue curve). The dotted line is the hypsometric curves given by the 40-m SPOT DEM (Gardelle et al., 2012).

\subsection{Soils and vegetation patterns}

In order to enhance the local accuracy of soil and vegetation descriptions that are currenlty available, a classification of surfaces into nine categories is defined based on field observations and soil characteritics measurements. This classification is spatially extrapolated using a semi-supervised classification of two Sentinel 2 images (Drusch et al., 2012) at a 10-m resolution for the two catchments studied. The values for soil depth and texture, root depth, vegetation type and vegetation fraction for each of the nine classes are shown on TABLE 4. In addition, other parameters needed for the parametrization of the models (e.g. leaf area index, surface albedo and surface emissivity) are taken from the ECOCLIMAP1 classification (Masson et al., 2003) for the representative ecosystems presented on TABLE 4. This parametrization of soil and vegetation is used in both models. The classification method and the characteritics of each class are described in detail by Eeckman et al. (2017). The surface classification established at the 10-m resolution is aggregated at the resolution of each model. The classification maps used to parameterize soil and vegetation in both models, for both the Kharikhola and Tauche catchments, are presented in FIGURE 3. The overall location of each class is consistent in both models, although the two different spatial 

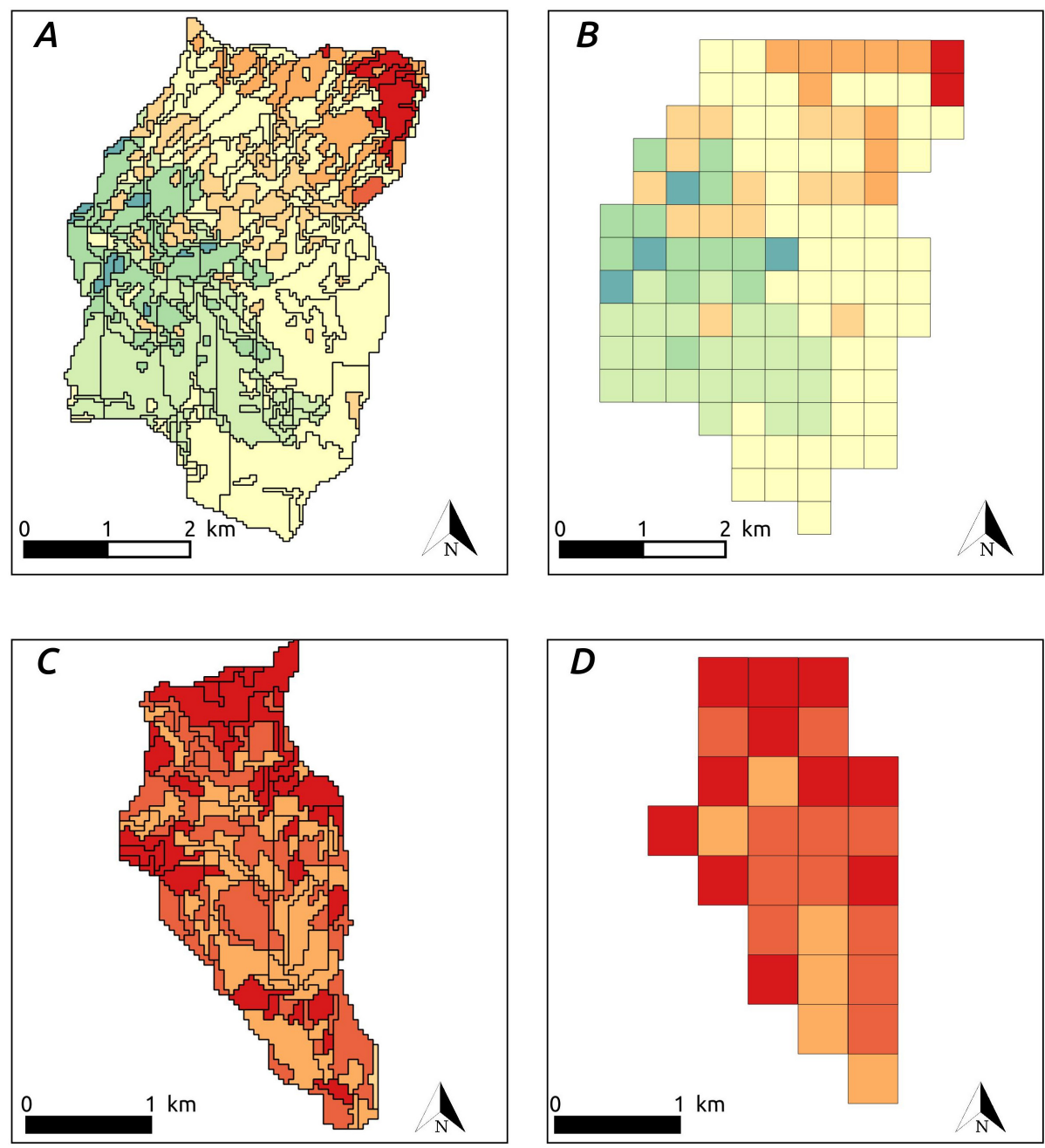

\section{Land use classification}
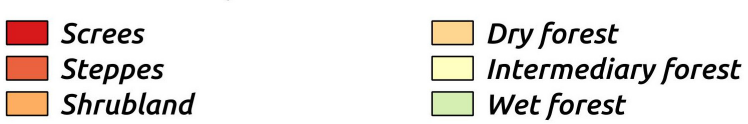

Slope crops Flat crops

Figure 3: Land cover classification defined for each HRU in the J2000 model: (A) on the Kharikhola catchment, (C) on the Tauche catchment; and on a regular 400-m resolution grid in ISBA: (B) on the Kharikhola catchment, (D) on the Tauche catchment. Each land cover class provides soil and vegetation characteristics established from in situ measurements.

\subsection{Climatic input}

Temperature and total precipitation are measured at 11 weather stations installed within the Dudh Koshi basin (see FIGURE 1). Reliable measurements for short- and long-wave radiation, atmospheric pressure, relative air humidity and wind speed are available at the Pyramid station, located at 5035 m.a.s.l., whithin the Sagarmatha National Park, Khumbu region, Nepal, and managed by the association Ev-K2-CNR, Bergamo-Italy (see FIGURE 
1). Hourly measurements for these variables are available at the Pyramid station from October 2002 to December 2004 ( at www.evk2.isac.cnr.it/). Hourly time series are computed from measurements over the three hydrological years 2013-2012, 2014-2015 and 2015-2016. The hydrological year is considered to start on April 1, as decided by the Department of Hydrology and Meteorology of the Nepalese Government and in general use (Savéan et al., 2015). Two seasons are defined: the summer season, from April 1 to October 30, that includes the monsoon and pre-monsoon periods, and the winter season, from November 1 to March 31.

Climatic variables are spatially interpolated according to the methods and values detailed in Eeckman et al. (2017):

- Air temperature measurements are spatially interpolated using a multi-linear method weigthed by the inverse distance (IDW method), coupled with a seasonal altitudinal lapse rate. The altitudinal lapse rate is computed from the observation : $-5.87^{\circ} \mathrm{C} . \mathrm{km}^{-1}$ for winter and $-5.64^{\circ} \mathrm{C} . \mathrm{km}^{-1}$ for summer.

- Total precipitation is interpolated using the method proposed by Valery et al. (2010): the IDW method is coupled to a multiplicative altitudinal factor $\beta$. The altitudinal factor $\beta$ is represented as a piecewise linear function of altitude. Altitudinal thresholds and lapse rates are optimized to provide optimal bias on annual discharge for both the Kharikhola and Tauche catchments. During the summer season, precipitation is considered to increase up to an altitudinal threshold of 3470 m.a.s.l. (3113 m.a.s.l. during winter) at a rate of $0.032 \mathrm{~km}^{-1}\left(1.917 \mathrm{~km}^{-1}\right.$ during winter $)$, then to decrease at a rate of $-1.382 \mathrm{~km}^{-1}\left(-1.83 \mathrm{~km}^{-1}\right.$ during winter) up to 3709 m.a.s.l. (4943 m.a.s.l. during winter). For higher altitudes, precipitation is considered to decrease at a rate of -0.283 $k m^{-1}\left(-0.191 \mathrm{~km}^{-1}\right.$ during winter).

- Long-wave radiation, atmospheric pressure and specific air humidity measurements at the Pyramid station are spatialized as a function of altitude, using the method proposed by Cosgrove et al. (2003). The hourly temperature is used to interpolate the atmospheric pressure based on the ideal gases law. The specific air humidity is 
deduced from the relative air humidity by combining the Wexler law and the definition of the saturating vapor pressure. The long wave radiation emitted is computed based on the air temperature using the Stefans law. Since short-wave radiation and wind speed have a quite low sensivity in the models in comparison with the other variables, these two variables are not spatially interpolated and are considered to be equal to the measurements at the Pyramid station for the two catchments studied.

This interpolation method for precipitation provides optimal precipitation fields for both the Kharikhola and Tauche catchments, for the two hydrological years 2014-2015 and 20152016, according to the discharges. However, the interannual variability is hardly represented in this interpolated data set. Indeed, these 2 years are very different. For the Kharikhola catchment, observed discharge at the outlet reached $48.3 \mathrm{~mm} /$ day in July 2014, whereas it did not exceed $24.5 \mathrm{~mm} /$ day in 2015-2016 (see FIGURE 4). For the Tauche catchment, the rainfall-runoff ratio was $53 \%$ in $2014-2015$ and $82 \%$ in $2015-2016$, considering interpolated precipitation and observed discharge TABLE 5). These variations can be due to the combined effects of (i) the effective interannual variability of climatic variables, (ii) errors in precipitation measurements, in particular concerning snowfall underestimation (Sevruk et al., 2009), (iii) errors in water level measurements or in the interpolation of discharge based on the rating curve. In particular, high discharge peaks might be overestimated when interpolated from the rating curve, because only a few gauging points are available for high water levels.

However, since the aim of this paper is to compare the hydrological responses of two models when using the same input data set, the choice was made not to consider uncertainties in hydro-climatic input data, but to focus on comparing the simulated responses of the two models.

\subsection{Discharges}

Hourly discharge time series are available at the hydrometric stations located at the Kharikhola outlet and at the Tauche outlet, from 2014-05-03 to 2016-05-20 and from 201405-07 to 2016-05-09, respectively (see TABLE 1). Two hydrometric stations were equipped 
with Campell@ hydrometric sensors. The rate curves for the two stations have been defined using 25 measurements in Kharikhola (from 0.020 to $7.48 \mathrm{~m}^{3} / \mathrm{s}$ ) and 19 measurements in Tauche (from 0.003 to $0.202 \mathrm{~m}^{3} / \mathrm{s}$ ). The time series at Kharikhola station contains $34 \%$ missing data in 2014-2015, due to a high monsoon flood which damaged the sensor. The time series at Tauche station contains no missing data, but additional observations made by a local observer indicated that the river was frozen from 2015-01-22 to 2015-02-28 and from 2016-01-08 to 2016-02-23. Discharge is considered as null during the frozen periods.

A particular attention has to be paid to the discharge peak happenning in June 2015 for the Tauche bassin. Indeed, the observed hydrograph increased from $0.06 \mathrm{~m}^{3} / \mathrm{sec}$ on 22 June to $0.3 \mathrm{~m}^{3} / \mathrm{sec}$ on 26 June (the highest peak of 2015). The precipitation is below $7 \mathrm{~mm}$ and remains throughout the period (the discharge event may not be due to precipitation events). The maximum temperature increased from $7^{\circ} \mathrm{C}$ to $8^{\circ} \mathrm{C}$ from 22 to 24 June and then decreased to $5.5^{\circ} \mathrm{C}$ in 25 June. The discharge event may then be due to either snow-melt fluxes or instrument error.

\subsection{Snow cover area}

The MOD10A2 product (Hall et al., 2002) provides the maximum snow cover extent over a 500-m resolution grid, at an 8-day time scale since 2000-02-26 to present. MOD10A2 is derived from the MODIS/Terra Snow Cover Daily product (MOD10A1). To compute the MOD10A2 maximum snow cover extent from MOD10A1 snow cover, the following condition is applied: if a pixel if considered as covered by snow at least once within each 8-day time lapse in the MOD10A1 product, this pixel is considered as covered by snow for the corresponding 8-day period in MOD10A2. MOD10A2 is commonly used in glaciological and hydrological studies in the western Himalayas (Shrestha et al., 2011; Panday et al., 2014; Pokhrel et al., 2014; Savéan et al., 2015; Nepal et al., 2017a). Moreover, the accuracy of this product was assessed in mountainous areas by various studies (Jain et al., 2008). In particular, Chelamallu et al. (2014) concluded that the MODIS products were more accurate in regions with substantial snow cover than in regions with low snow cover. 


\subsection{Modelling strategies}

Observed discharges were available for only 1 complete hydrological year (2015-2016) at the Kharikhola catchment and for 2 hydrological years at the Tauche catchment (2014-2016). The ISBA and J2000 simulations over these catchments were run separately from 2013-0101 to 2016-03-31. The 2013-2014 year was used as a spin-up period and the results were observed for the 2014-2016 hydrological years. The ISBA was run at an hourly time scale and hourly model outputs were aggregated to the daily level. The ISBA routing module was calibrated over the whole period of available discharge observations. No independent validation period was then considered here due to the short period of observed data. The choice has been made to apply the J2000 model at a daily time step, in order to be consistent with the work of Nepal et al. (2011) (see Section 2.2). Indeed, the calibrations of J2000 provided by Nepal et al. (2014) might not be valid at the hourly time step. Considering the very short period of availability of the water level measurements for the two studied catchments, a new calibration of J2000 in this work would not be feasable. For this reason, the choice has be made to keep using a daily time step to run J2000.

Model performance was assessed against observed discharge data using the four efficiency criteria : coefficient of determination $r^{2}$, Nash-Sutcliffe Efficiency (NSE), NSE for the square root of discharges $\left(N S E_{\text {sqrt }}\right)$ and relative bias $\left(\right.$ Bias $\left._{r}\right)$, computed at the daily time scale. The $N S E_{\text {sqrt }}$ has the property of flattening flow peaks and therefore it is used to assess performance for low-flow periods (Zhang et al., 2007). To assess performance for high-flow, the NSE criteria is also computed separately for the high flow periods, i.e. from June 1 to September 30. This criterion is noted $N S E_{h i g h}$.

\section{Results and discussion}

TABLE 5 presents annual volumes for total precipitation, solid precipitation, evapotranspiration, discharge and snow-melt contribution, in annual average over each of the two catchments studied. FIGURE 4 and FIGURE 5 present the dynamics of simulated variables in both models, respectively for the Kharikhola and Tauche catchments. This section aims to investigate in detail the differences and the similarities between the two modelling ap- 
proaches in order to better describe the uncertainties associated with model structure in the estimation for the annual water budgets provided in the litterature.

\subsection{Evaluation against observed discharge}

FIGURE 4 and FIGURE 5 show the simulated and observed hydrographs in the Kharikhola and Tauche catchments, respectively. TABLE 5 presents the performance of both models for four different efficiency criteria computed at the daily time scale.

Annual relative bias on discharge for the Kharikhola catchment is satisfactory for 20152016 for both models ( $-9.7 \%$ for ISBA and $0.04 \%$ for J2000), but the discharge at the Kharikhola outlet is strongly under-estimated for 2014-2015 for both models (Bias $r$ is $45.7 \%$ for ISBA and $-37.1 \%$ for J2000). On the Tauche catchment, the observed discharges are under-estimated for both years, for both models, with average Bias $s_{r}$ values of $-15.6 \%$ for ISBA and $-20.90 \%$ for J2000. These under-estimations are due to the under-estimation of total precipitation for the corresponding years, as presented section 2.5.

For the two hydrological years, the dynamics of the observed discharges is accurately represented by the two models for the two catchments, with the annual average of $r^{2}$ greater than 0.72 and NSE values greater than 0.70. During the summer season, the discharge dynamics is driven by precipitation, with a quick response of the surface runoff for both catchments. These quick flow variations are satisfactorily represented by both models.

Low flows including rising and recession periods are accurately captured for both years by both models for the Kharikhola catchment: on average over the 2 years, $N S E_{\text {sqrt }}$ is 0.77 for IBSA and 0.82 for J2000. For the Tauche catchment, low flows are clearly represented for 2014-2015 (NSE sqrt is 0.78 for ISBA and 0.76 for J2000). The representation of high-flow peaks in the summer season is very satisfactory for the Kharikhola catchment in 2015-2016 and for the Tauche catchment in 2014-2015 (NSE high values greater than 0.66).

An interesting period of discordance between the two models occurs between March 2015 and June 2015 (pre-monsoon period) on the Tauche catchment. During this period, the 
ISBA model simulates a fast-responding discharge, whereas the seasonal inscreasing of the discharge simulated with the J2000 model is slower. Despite boths models under-estimate the observed discharge, the discharge simulated with ISBA during this pre-monsoon period are greater than the discharge simulated with J2000. In order to better understand this period of discrepancies between the two models, each of the components of the water budget are described in the following section, and in particular their behavior during this pre-monsoon 2015 period.

\subsection{Components of annual water budgets}

\subsubsection{Precipitation}

Slight differences exist for total precipitation between the J2000 and ISBA models, although the same precipiation input is provided for both models. These differences stem from the spatial discretization methods used in both models for precipitation spatial interpolation (see section 2.3). Indeed, even though the input grid data provided for precipitation are the same for both models, precipitation is further interpolated by J2000 from the grid scale to the HRU scale, using the inverse distance weighting method. However, for both catchments, the difference in total precipitation between the two models represents less than $1 \%$ of the annual volume $(0.98 \%$ for the Kharikhola catchment and $0.45 \%$ for the Tauche catchment). The difference between both models for total precipitation can then be considered as negligible.

Regarding the solid precipitation, the annual volumes considered in the two models also differ. For the Kharikhola catchment, this difference is about $7 \mathrm{~mm}$ (representing $1.1 \%$ of annual average solid precipitation) and can then be considered as negligible. But, for the Tauche catchment, the average solid precipitation is $219 \mathrm{~mm}$ higher for ISBA than for J2000. This difference represents about $40 \%$ of the annual volumes of solid precipitation. This significant difference is mainly due to the difference in the time step used for precipitation phase distribution in both models. Indeed, despite both total preciptiation and temperature fields are provided for both models at the hourly time step, the precipitation phase in J2000 is computed at the daily time step, whereas it is computed at the hourly time step in ISBA. However, as specified in section 2.8, the purpose of this work is to stay consistent with the previous studies that uses these models. The infra-daily variations of solid precipitation is 
then missed in J2000 (see section 3.3 for further analysis). This point shows that the time step used for the partition of precipitation phase strongly influences the simulation results. The propagation of this difference toward the simulated water budgets in the two models is futher investigated.

\subsubsection{Discharge components}

In ISBA, the surface overland flow is considered as the sum of the simulated Dunnes flow and Hortons flow (see section 2.1). In J2000, the Dunne and Horton flows mechanisms are not separated and the simulated surface runoff comprises both saturation and infiltration excess runoff. The drainage flow at the bottom of the soil column in ISBA is comparable to the sum of the three flows in the soil in $\mathrm{J} 2000$ ( $R D 2, R G 1$ and $R G 2$ ). The following comparison is given on average over the two hydrological years studied.

For ISBA, the Hortonian runoff represents less than $1 \%$ of discharge on the Tauche catchment and about $5 \%$ of discharge on the Kharikhola catchment. While in ISBA, this means than the surface flows occur mainly (on the Kharikhola catchment) or almost only (on the Tauche catchment) by the saturation of soil reservoirs rather than by excess infiltration capacity.

For the Kharikhola catchment, the annual volume of drainage (i.e. sub-surface flow) represents $77 \%$ of the discharge at the outlet for ISBA (drainage flow at the bottom of the soil column) and $87 \%$ for J2000 (sum of the RD2, RG1 and RG2 flows). For the Tauche catchment, this volume is $70 \%$ for ISBA and $85 \%$ for J2000 of the annual discharge. The annual overland flow represent $30 \%$ of the annual discharge for ISBA and $13 \%$ for J2000 on the Kharikhola catchment. For the Tauche catchment, this volume is $23 \%$ for ISBA and $15 \%$ for J2000. These figures highlight the significant contribution of soil water to discharge for both middle- and high-mountain catchments.

Therefore, this model intercomparison reveals that most discharge at the outlet is provided by drainage. This result is consistent with the description of soils for the two catchments: sandy soils allow fast infiltration, resulting in a larger fraction if the flow occuring in the soils than on the surface. However, the definition of drainage strongly differs between the two 
models. Indeed, in ISBA, the drainage represents the vertical flow at the bottom of the soil column (without routing nor delays), whereas in J2000, it represents the sum of the outflows from the soil water module.
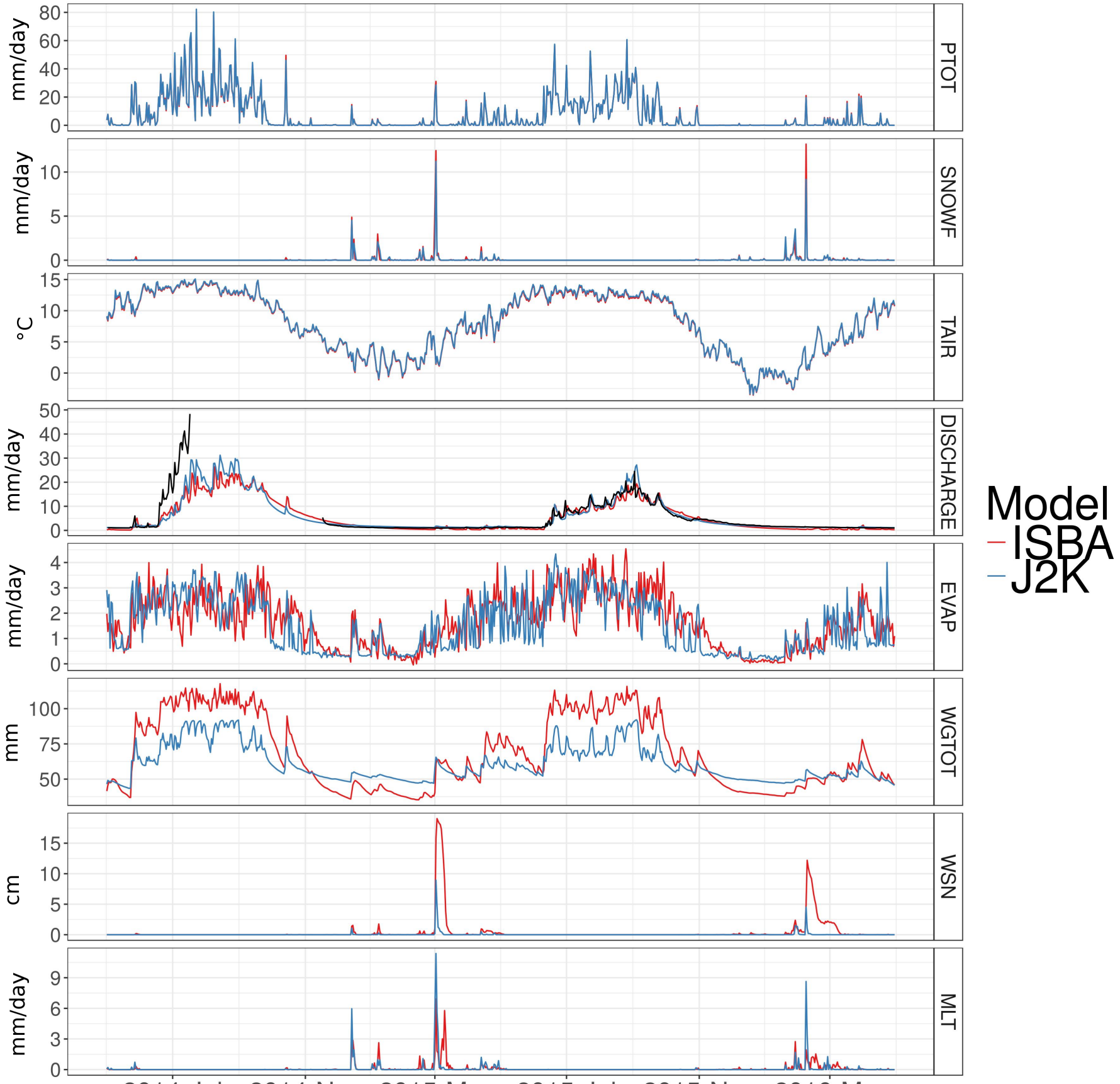

2014-Jul 2014-Nov 2015-Mar 2015-Jul２015-Nov 2016-Mar

Figure 4: Daily time series for input variables : total precipitation (PTOT), solid precipitation (SNOWF) and air temperature (TAIR) and for variables simulated by ISBA and J2000 models at the daily time scale : discharge at the outlet (DISCHARGE), actual evapotranspiration (EVAP), soil water content (WGTOT), snow water equivalent (WSN) of the snow pack and snow-melt (MLT), for the 2014-2015 and 2015-2016 hydrological years, for the Kharikhola catchment. Black line is the daily observed discharge at the outlet. 


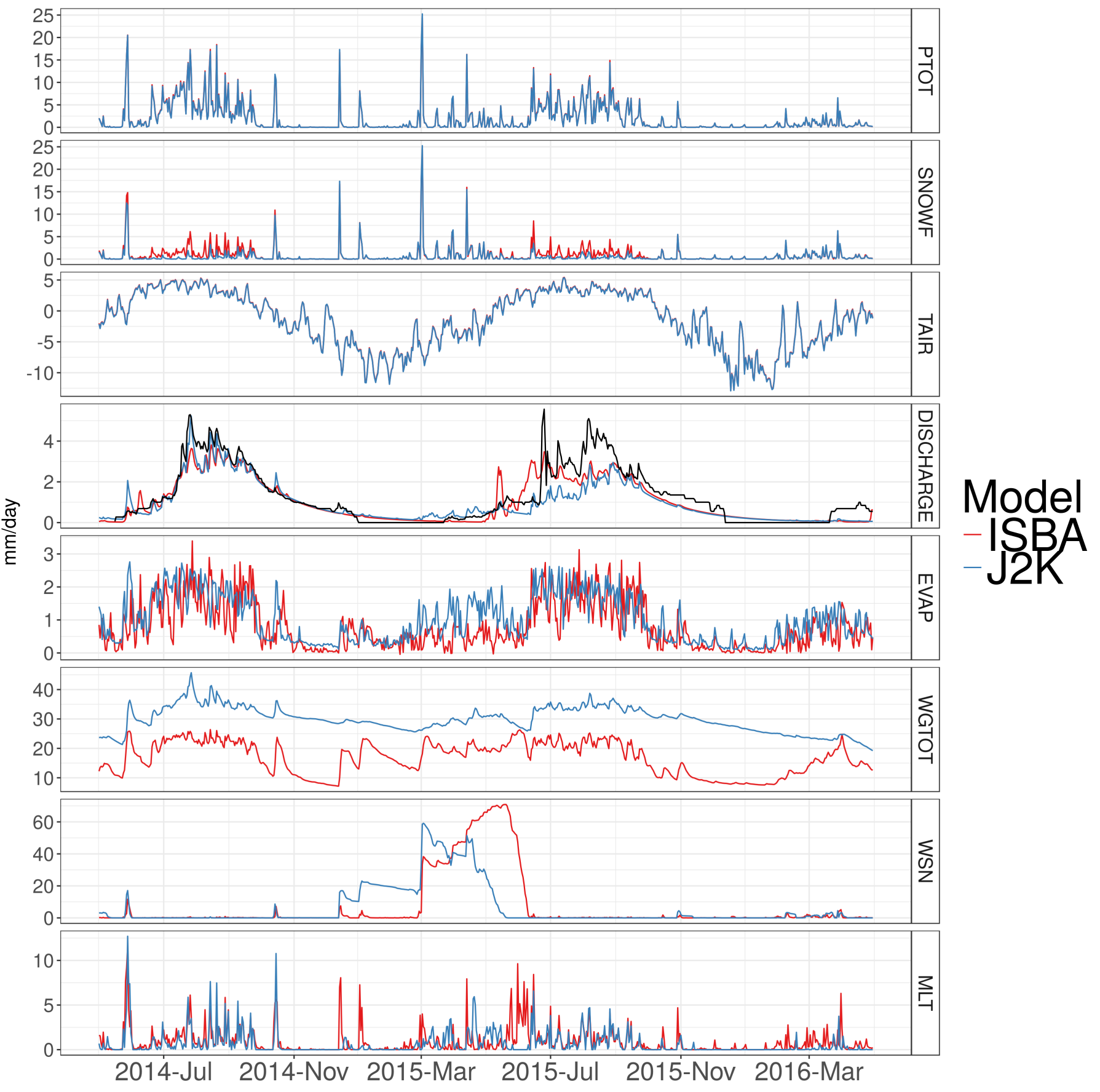

Figure 5: Daily time series for input variables : total precipitation (PTOT), solid precipitation (SNOWF) and air temperature (TAIR) and for variables simulated by ISBA and J2000 models at the daily time scale : discharge at the outlet (DISCHARGE), actual evapotranspiration (EVAP), soil water content (WGTOT), snow water equivalent (WSN) of the snow pack and snow-melt (MLT), for the 2014-2015 and 2015-2016 hydrological years, for the Tauche catchment. Black line is the daily observed discharge at the outlet.

\subsubsection{Soil water content}

The conceptualizations of the soil water storage in both models are very different (see TABLE 2). Considering these structural discrepancies, the total water content of the soil column simulated in ISBA can be compared to the sum of the volumes stored in MPS and LPS reservoirs in J2000. 
During the high-flow periods (between June and October), the dynamic of the soil water content simulated with both models appear to be fast-responding to precipitation. The timing of the simulated soil water content also matches well between both models. However, on the Kharikhola catchment, the soil water content simulated with ISBA is lower than with J2000 during low flow period, but this behavior is reversed during high flow period, with greater soil water content simulated in J2000 than in ISBA. On the Tauche catchment, the soil water content is permanently higher in J2000 than in ISBA.

This behavior can be explained by the fact that, in ISBA, the simulated soil water content is limited by the soil humidity at saturation $\left(w_{\text {sat }}\right.$, in $\left.\mathrm{mm}\right) . w_{\text {sat }}$ values are calculated according to Clapp and Hornberger (1978), as a function of soil texture. In J2000, the volume stored in each reservoir MPS and LPS is limited by maximum volumes maxMPS and maxLPS, respectively. $\operatorname{maxMPS}$ and $\max L P S$ are computed according to soil texture for each HRU. The TABLE 6 presents the average values of $w_{\text {sat }}$, $\max M P S$ and $\max L P S$ for the Kharikhola and Tauche catchment. Provided value for $w_{\text {sat }}$ is greater than the sum $\max M P S+\max L P S$ for the Kharikhola catchment, but it is lower for the Tauche catchment. This parametrization can explain that the soil water content is globally higher in ISBA than in J2000 for the Kharikhola catchment, but lower in ISBA than in J2000 the the Tauche catchment. This point illustrates the fact that the representation of soil water content significantly varies between these two models, as well as in other studies (see Introduction).

\subsubsection{Evapotranspiration}

On average over the 2 hydrological years, the estimation of annual actual evapotranspiration (actET) on the Kharikhola catchment was $22.6 \%$ of total annual precipitation with ISBA and $19.8 \%$ with J2000. On the Tauche catchment, it was $34.4 \%$ with ISBA and 50.6\% with J2000 of the total annual precipitation. These values include bare soil evaporation, vegetation transpiration and snow sublimation. ActET for the two models in both catchments correlated acceptably at the daily time scale, with $r 2=0.48$ for the Kharikhola catchment and $r 2=0.38$ for the Tauche catchment. However, a major difference can be seen in the pre- 
monsoon period (March-June) in the Tauche catchment where simulated actET is higher in J2000 (up to $2 \mathrm{~mm} /$ day) than in ISBA (less than $0.5 \mathrm{~mm} /$ day). This delay in the increasing of actET in ISBA is due to late simulated snow-melt in ISBA. Indeed, the simulated snow pack, that limits the evaporation simulated over bare ground, remains in ISBA until June 2015, whereas it melts from March 2015 in J2000. This point indicates that the simulation of the snow-melt contribution significantly influences the simulation of both the discharge at the outlet and the evapotranspiration.

\subsubsection{Snow-melt contribution}

For both models, the contribution of snow-melt to discharge is less than $1.5 \%$ for the Kharikhola catchment. This point can then be considered as a robust result and it allows to enhance the actual understanding of the hydrological cycle for a middle-mountain catchment. For the Tauche catchment, the contribution of snow-melt accounts for $45.3 \%$ of the annual simulated discharge in ISBA results, and $33.2 \%$ of the annual simulated discharge in J2000 results. For the Tauche catchment (see FIGURE 5), both models provide the majority (73\% in ISBA and $82 \%$ in J2000) of snow-melt during the summer season. The timing of snowmelt between July and November (monsoon and post-monsoon periods) are similar in both models. However, the dynamic of the simulated snow-melt occurring between March and July 2015 significantly differs between the two models: On March, 2nd. a snow precipitation (25 $\mathrm{mm}$ in one day) leads to a sharp increasing of the snow-pack water equivalent in both models. However, in J2000, the snow-pack starts melting after this studden snow fall, with snow-melt variations concomitant with snow falls. On the contrary, the snow-pack simulated with ISBA keeps accumulating the subsequent snow falls until May, 20th. These different dynamics of the simulated snow-pack in the two models explain the discrepancy not only of the simulated discharge but also of the simulated evapotranspiration between both models during this period. In order to further criticize these simulated snow pack, the MOD10A2 maximum snow extent product is compared to the simulation results (see section 3.4).

Note that occasionally ISBA simulates snow melt for air temperatures below freezing, but only during winter, when the temperatures are low but also the cumulated snow packs are thin. This arises for essentially two reasons; i) solar radiation transmitted through the 
snowpack when it is fairly thin and radiation is fairly high (over $800 \mathrm{~W} \cdot \mathrm{m}^{-2}$ for the melting events in question) can reach the soil below thereby heating it sometimes substantially and to values above freezing thereby causing melt from below, and ii) when the snow is shallow the snow fraction tends to be low therefore the non-snow covered fraction of the grid cell warms considerably owing to the large solar radiation (well above freezing). This leads to an over-estimation of the soil temperature, that provokes snow melt at the bottom of the snow pack. The second effect can be argued to be not very physically realistic, but the goal of this study is not to develop a new physic parameterization but to use the model as-is. This reveals one the limitations of the sub-grid parameterization of the snow pack in ISBA when snow is concomitant with very high solar radiation at very high altitudes. Since ISBA's snow fraction parameterization is quite standard among large scale models, this study underscores that improvements should be made for the specific geographic context in this study. Moreover, for ISBA, the infra-daily variations of the air temperature significantly influence snow-melt (see section 3.3).

\subsection{Sub-daily variation of snow processes}

In order to better understand the difference between the two models for snow processes representation, the sub-daily variations of snow processes are investigated for the Tauche catchment. The FIGURE 6 presents the hourly dynamics of input variables of the ISBA and J2000 models (total precipitation, solid precipitation and air temperature) and the simulated snow melt in both models, for the two seasons. It can be observed that, at the hourly time step, the dynamics of solid precipitation reproduce the dynamics of total precipitation for both seasons. However, the typical sub-daily dynamics for total and solid precipitation and for snow melt significantly differ between the two seasons. During the summer season, solid precipitation is maximum at around 5 am (usually before sunrise) and minimal in the afternoon. This can be explained by the fact that, during the monsoon period, the air humidity is permanently close to saturation. The limiting factor for water condensation is then the air temperature. Consequently, precipitation happens when the air temperature is low enough for the dew point to be reached. In winter, solid precipitation is more important between $18 \mathrm{pm}$ and 3 am than during the day. As during the monsoon period, total precipitation increases around $18 \mathrm{pm}$ when the air temperature starts decreasing. However the air humidity 
being globally low during winter, the air get quickly too dry for condensation to happens. Consequenly, total (and solid) precipitation remain low during the day. The daily dynamic of solid precipitation during winter is then not particularly significant.

The hourly dynamic of the snow melting is a resultant of both the solid precipitation dynamic and the air temperature dynamic. During the summer season, the snow melting is driven by both the increasing of the air temperature in the afternoon and the increasing of solid precipitation during the night. This leads to a bimodal hourly dynamic for the snow melting simulated in ISBA. However, since these snow melt peaks are not compensated by a decreasing during the night, the daily average of the snow melting simulated with ISBA is greater than with J2000. During the winter season, the hourly dynamics of the snow melting is mainly driven by the air temperature. The snow pack mainly melts during the afternoon and it is refilled by snow melt happenning during the night. This leads to a daily average of the snow melting simulated with ISBA greater than with J2000 during the winter season.

This analysis of the sub-daily dynamics of the snow pack simulated at the hourly time step in ISBA explains the difference between both models for the simulation of the snow processes and in particular the fact that the snow-melt contribution is more important in ISBA than in J2000. This kind of analysis based on hourly simulation is actually pretty rare in the litterature. In particular, the analysis of the sub-daily variation of the air temperature in a high-elevation himalayan catchment presented by Heynen et al. (2016) is consistent with the behavior presented here.

\subsection{Comparison with MOD10A2 maximum snow extent}

The simuled snow cover area (SCA) is computed by applying a threshold condition on the simulated snow depth (in ISBA) and on the simulated snow water equivalent (in J2000). For each time step (hourly time step in ISBA, daily time step in J2000), each unit of the model (grid cell for ISBA, HRU for J2000) is considered as covered by snow if the snow depth is greater than $60 \mathrm{~mm}$ (in ISBA) or if the snow water equivalent is greater than $40 \mathrm{~mm}$ (for J2000). These values are consistent with values used by Biskop et al. (2016) on the Tibetan Plateau and by Gascoin et al. (2015) in the Pyrenees. 


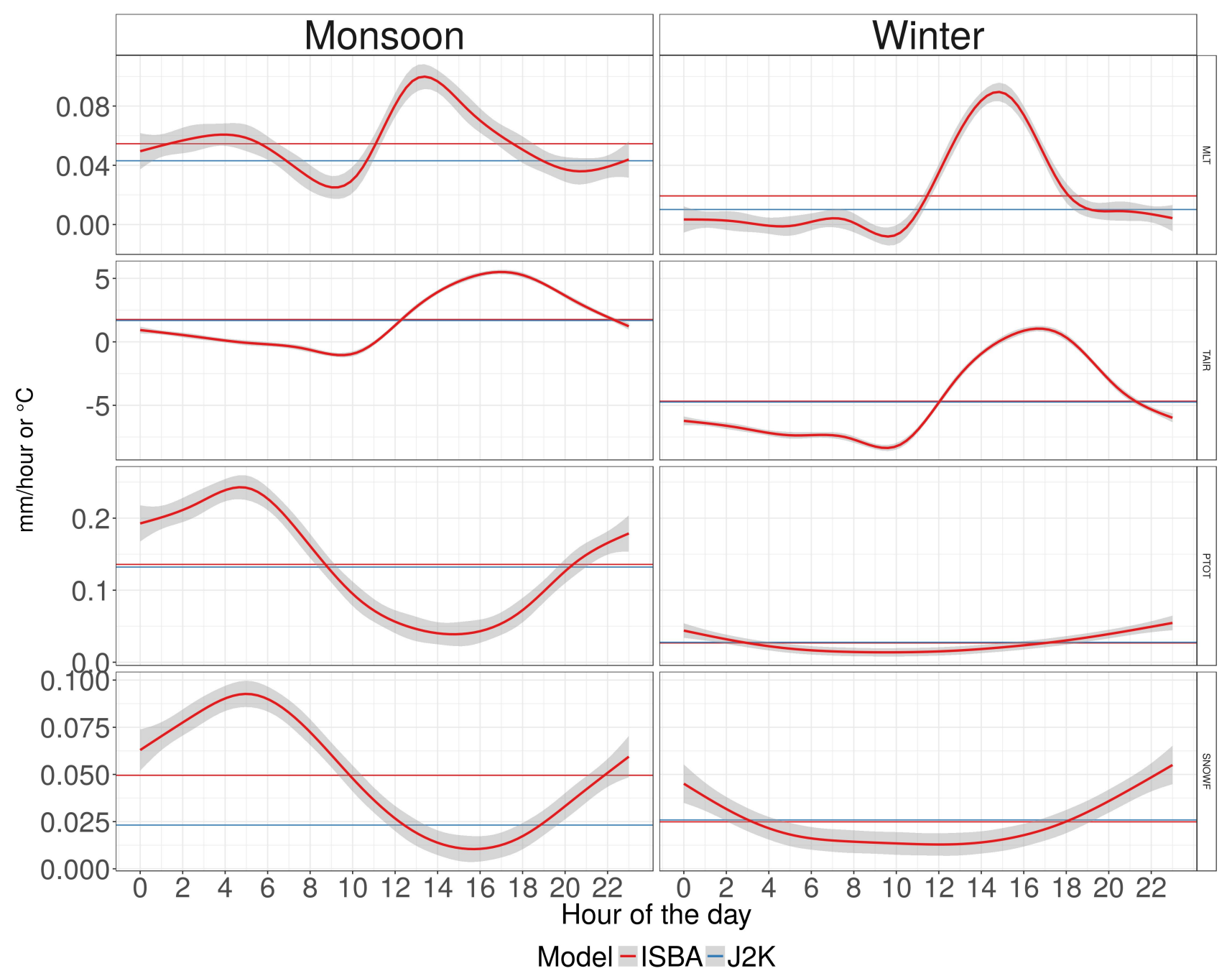

Figure 6: Hourly dynamics of input variables of the ISBA and J2000 models: total precipitation (PTOT), solid precipitation (SNOWF) and air temperature(TAIR) and the simulated snow melt in both models (MLT), for the two seasons, on average over the Tauche catchment. The continuous line represents the average hourly value (in mm per hour) for input variables or for simulated variables in ISBA. The grey interval represent the associated $95 \%$ confidence interval. The horizontal line represents the daily means (in mm per hour) of these variables in the two models. 
Daily simulated SCA and MOD10A2 maximum snow extent is compared in FIGURE 7, on spatial average over the Tauche catchment, for the 2 hydrological years 2014-2015 and 2015-2016. The overall timing of the MOD10A2 SCA is well reproduced by both models, with a significant snow period occurred between December 2014 and June 2015 and no significant snow pack was simulated or observed between July 2015 and March 2016. The maximum value of SCA (66\%) is reached for both model on March, 2nd 2015. This value and timing is also consistant with the MOD10A2 values. Moreover, this comparison leads to two main analyzes. First, the short-duration peaks of SWA are better represented with ISBA than with J2000, despite they remain underestimated by about one-third compared to the MOD10A2 values. This point highlights the fact that using a hourly time step allows to better represent infra-daily processes. This processes are further described in section 3.3. Second, snow-melt occurring during the pre-monsoon period (between March 2015 and May 2015) was faster in J2000 than in ISBA. In particular the SCA simulated with ISBA is bound around $0.5 \%$ over 2 months. The snow pack parametrization in J2000 being calibrated according to the MOD10A2 SCA and the six snow parameters being particularly adapted for the Tauche catchment, the simulated SCA is forced to reproduced the MOD10A2 values in J2000. However, the snow pack accumulation simulated with ISBA appears to overestimate the MOD10A2 values during this period. This over-estimation could in particular be explained by the fact that the land-aspect is not parametrized in ISBA, despite it can significantly influence the snow pack simulation for such contrasted relief.

\section{Conclusion}

This paper aims to assess the impact of using a different degree of refinement to model hydrological processes at the local scale in sparsely instrumented mountainous catchments. The methods and results of two approaches that have been previously applied in this region are compared, namely the work of Eeckman (2017) that uses the ISBA (Interaction Sol-Biosphere-Atmosphere) surface and the work of Nepal et al. (2014) that uses the J2000 distributed hydrological model. The ISBA and J2000 models are applied to two small catchments located in mid- and high mountain environment within the Everest region. In this 


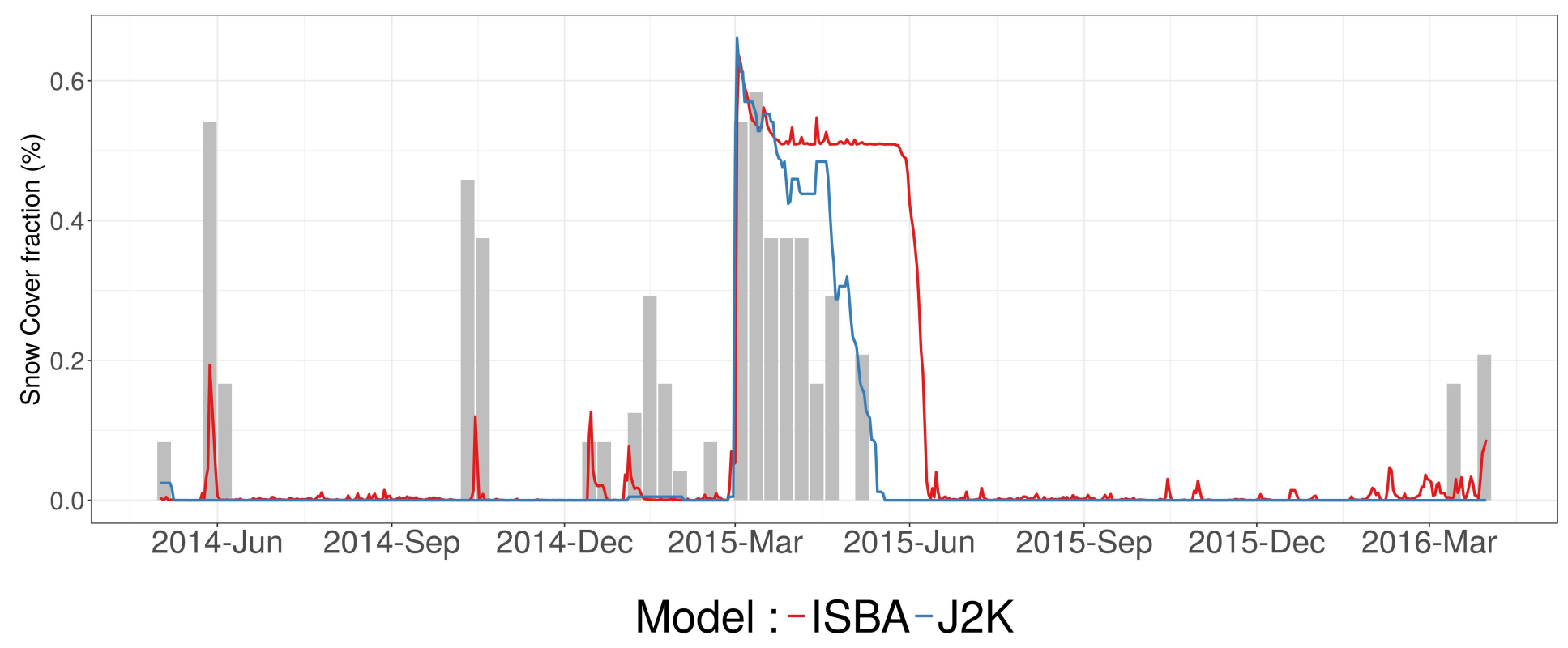

Figure 7: Snow cover area simulated by ISBA and J2000, aggregated at the daily time scale, on average over the Tauche catchment, for the 2014-2015 and 2015-2016 hydrological years. Grey bars are MOD10A2 maximal snow cover extend, on average over the Tauche catchment, at a 8 days time scale.

framework, several points should be underlined:

1. Since conceptual models rely more on calibration data, the reliability of a calibrated approach was tested by comparing it to an approach based on energy balance solving in an environment where data quality and quantity is relatively low. One of the main results of this study is that both models overally represent the dynamics of the processes for evaporation, quick runoff and discharge in a similar way. Estimations of annual volumes for these components of the water budget are provided and they can be considered as a contribution to the current knowledge of the hydro-systems in this region.

2. An interesting period of discrepancy between the two models is found for the high mountain catchment at the beginning of the monsoon 2015. In this case, the snow-pack simulation is shown to be the main driver of the discrepancy between the two models. This work also analyses in details the sub-daily variation of snow processes. The time step used in the model (daily or hourly time step) is shown to strongly influence the precipitation phase partition and consequently the snow-melt contribution to discharge, in particular during the summer season. This work leads then to suggest for upcoming researches that modelling approaches should be set up at a sub-daily time step in order to represent the significant sub-daily variations of snow-melt processes. 
3. The contribution of drainage in the soil are shown to be more important than the runoff contribution to discharges for both models and for the two catchments. This result is consistent with the physical descriptions of soils based on in-situ measurements, that describe fast-infiltrating, mostly sandy soils. However, this work exposes that the structural hypotheses made in the two models significantly influence the simulation of water storages and flows in the soil, in particular for the high mountain catchment. This point illustrates the fact that, since the conceptualization of the soil processes differs in the different studies in the litterature, the estimations of these processes are associated with important uncertainties due to the model structure.

4. Finally, this model comparison work performed at a local scale allows to analyse the local accuracy of the distributed modelling approach proposed by Nepal et al. (2011), that is available at a larger scale over the Dudh Koshi basin. This work applies then the idea that, in a context where a very few data is available for the estimation of the performances of the simulations, model inter-comparison can then be used as an alternative way to estimate simulation robustness.

Based on this research, both models present equivalent results for dischage and evapotranspiration simulation in middle- and high-mountain environments. They could be used for operational purposes in two complementary ways: (i) the assessment of water availability considering new scenarios of climate forcing or land use and land cover change and (ii) the sizing of hydraulic installations for agriculture, domestic water supply or hydropower, on the request of the local water users.

\section{Appendix A. The HDSM routing module coupled to ISBA}

The routing module coupled to the ISBA surface scheme is taken from the HDSM hydrological model (Delclaux et al., 2008). The transfer function of HDSM is derived from the THMB model (Coe, 2000). The HDSM model has already been applied for various studies, but this study is the first application of the routing module coupled to the ISBA surface scheme. The HDSM model has been applied by Savean, 2015 on the Dudh Koshi basin and showed good performances for discharge and snow cover area modelling. 
For each cell, surface runoff $\left(R_{s}\right)$, given by the sum of Dunne runoff and Horton runoff,

and the drainage at the bottom of the soil column $\left(R_{d}\right)$ are directed toward two simple linear reservoirs, $W_{s}$ and $W_{d}$ respectively. $W_{s}$ and $W_{d}$ are characterized by a residence time $\left(T_{s}\right.$ and $T_{d}(\mathrm{~s})$, resp.) and a volume $\left(V_{s}\right.$ and $V_{d}\left(m^{3}\right)$, resp.). $W_{s}$ and $W_{d}$ are governed by EQUATION A.1.

$$
\left\{\begin{array}{c}
\frac{\mathrm{d} V_{s}}{\mathrm{~d} t}=R_{s}-\frac{V_{s}}{T_{s}} \\
\frac{\mathrm{d} V_{d}}{\mathrm{~d} t}=R_{d}-\frac{V_{d}}{T_{d}}
\end{array}\right.
$$

At each time step, the sum of the outflows from $W_{s}$ and $W_{d}$ is directed toward a linear routing reservoir $W_{r}$. $W_{r}$ is characterized by a volume $V_{r}\left(m^{3}\right)$ and a residence time $T_{r}(\mathrm{~s})$. The outflow of $W_{r}\left(R_{\text {out }}\right.$, in $\left.\mathrm{m}^{3} / \mathrm{s}\right)$ is computed as in EQUATION A.2.

$$
R_{\text {out }}=\frac{V_{r}}{T_{r}}
$$

The residence time in the transfer reservoir is defined for each mesh point as the ratio between the flow velocity $\left(\mathrm{u}\right.$, in $\left.m \cdot s^{-1}\right)$ and the distance from the center of the mesh point to the center of the previous upstream mesh point ( $d$, in $m$ ). The flow velocity is calculated as the ratio of the mesh point slope $\left(i_{c}\right.$ in $\left.m \cdot m^{-1}\right)$ and a reference slope $\left(i_{0}\right.$ in $\left.m \cdot m^{-1}\right)$, taken equal to the catchment median slope. This ratio is weighted by a $c_{v e l}$ transfer coefficient (see EQUATION A.3). $c_{v e l}$ is calibrated as a uniform parameter.

$$
\left\{\begin{array}{l}
T_{r}=\max \left(\frac{d}{u}, \Delta t\right) \\
u=\text { cvel. } \sqrt{\frac{i_{c}}{i_{0}}}
\end{array}\right.
$$

This coupling then requires the calibration of the parameters $T_{r}, T_{d}$ and cvel. These parameters are calibrated against the observed discharges at the outlets, according to the NSE criteria, the biais computed on daily discharges and to the NSE criteria computed on the square root of the daily discharge $\left(N S E_{s q r t}\right)$. Optimum parameter sets are computed using the Pareto's optimum method. Initial ranges of parameter values for calibration are taken from Savéan (2014). Considering the few available discharge measurements, the entire observation period is used for calibration. 
The calibration is run out independently for the Kharikhola and Tauche catchments. The

optimal parameter set for each basin, as well as the calibrated values for the Dudh Koshi basin by Savéan et al. (2015), are presented in TABLE A.7. The performances according to the three criterias are satisfactory for both basins. Low discharges are better simulated for the Kharikhola basins $\left(N S E_{\text {sqrt }}=0.80\right)$ than for the Tauche Basin $\left(N S E_{\text {sqrt }}=0.77\right)$. Residence times $t_{s}$ and $t_{d}$ are shorter for the Tauche Basin than for the Kharikhola Basin. Residence times calibrated by Savéan et al. (2015) for the Dudh Koshi Basin are shorter than for the two sub-basins. In addition, the cvel transfer coefficient is significantly higher for the Dudh Koshi Basin than for the two sub-basins. More physical interpretations for these calibrated values can be found in Eeckman (2017).

\section{Acknowledgments}

The authors address special thanks to Professor Isabelle Sacareau (Passages Laboratory of the CNRS and Montaigne University of Bordeaux, France), coordinator of the PRESHINE Project. They are also grateful to the hydrometry team and the administrative staff of the Laboratoire Hydrosciences Montpellier, France, the hydrologists and glaciologists of the Institut des Geosciences de l'Environnement in Grenoble, France, the meteorologists of the Centre National de la Recherche Meteorologique in Toulouse and Grenoble, France, the Association Ev-K2 CNR and the Pyramid Laboratory staff in Bergamo, Italy, Kathmandu and Lobuche, Nepal as well as the Vice-Chancellor of the Nepalese Academy of Science and Technology (NAST) and its staff, especially Devesh Koirala and Anjana Giri. The views and interpretations in this publication are those of the authors and are not necessarily attributable to their institutions.

\section{Funding}

This work was funded by the Agence Nationale de la Recherche (references ANR-09CEP-0005-04/PAPRIKA and ANR-13-SENV-0005-03/PRESHINE), Paris, France. It was locally approved by the Bilateral Technical Committee of the Ev-K2-CNR Association (Italy) and the NAST within the Ev-K2-CNR/NAST Joint Research Project. It is supported by 
the Department of Hydrology and Meteorology, Government of Nepal. The study was also supported in part by ICIMODs Cryosphere Initiative funded by Norway, and core funds contributed by the Governments of Afghanistan, Australia, Austria, Bangladesh, Bhutan, China, India, Myanmar, Nepal, Norway, Pakistan, Sweden and Switzerland.

\section{References}

Andermann, C., et al., 2012. Impact of transient groundwater storage on the discharge of himalayan rivers. Nature Geoscience, 5 (2), 127-132.

Anders, A.M., et al., 2006. Spatial patterns of precipitation and topography in the himalaya. Geological Society of America Special Papers, 398, 39-53.

Barros, A., et al., 2004. Probing orographic controls in the himalayas during the monsoon using satellite imagery. Natural Hazards and Earth System Science, 4 (1), 29-51.

Bharati, L., et al., 2016. Past and future variability in the hydrological regime of the koshi basin, nepal. Hydrological Sciences Journal, 61 (1), 79-93.

Biskop, S., et al., 2016. Differences in the water-balance components of four lakes in the southern-central tibetan plateau. Hydrology and Earth System Sciences, 20 (1), 209-225.

Bookhagen, B. and Burbank, D.W., 2006. Topography, relief, and trmm-derived rainfall variations along the himalaya. Geophysical Research Letters, 33 (8). Available from: http://dx.doi.org/10.1029/2006GL026037.

Boone, A., et al., 2000. The influence of the inclusion of soil freezing on simulations by a soilvegetation-atmosphere transfer scheme. JOURNAL OF APPLIED METEOROLOGY, 39 (9), 1544-1569.

Boone, A. and Etchevers, P., 2001. An intercomparison of three snow schemes of varying complexity coupled to the same land surface model: Local-scale evaluation at an alpine site. Journal of Hydrometeorology, 2 (4), 374-394. Available from: http://dx.doi.org/10.1175/1525-7541(2001)002¡0374:AIOTSS¿2.0.CO;2. 
Chelamallu, H.P., Venkataraman, G., and Murti, M., 2014. Accuracy assessment of modis/terra snow cover product for parts of indian himalayas. Geocarto International, $29(6), 592-608$.

Clapp, R.B. and Hornberger, G.M., 1978. Empirical equations for some soil hydraulic properties. Water Resources Research, 14 (4), 601-604. Available from: http://dx.doi.org/10.1029/WR014i004p00601.

Coe, M.T., 2000. Modeling terrestrial hydrological systems at the continental scale: Testing the accuracy of an atmospheric gcm. Journal of Climate, 13 (4), 686-704.

Cosgrove, B., et al., 2003. Real-time and retrospective forcing in the North American Land Data Assimilation System (NLDAS) project. JOURNAL OF GEOPHYSICAL RESEARCH-ATMOSPHERES, 108 (D22).

Decharme, B., et al., 2011. Local evaluation of the interaction between soil biosphere atmosphere soil multilayer diffusion scheme using four pedotransfer functions. Journal of Geophysical Research: Atmospheres, 116 (D20).

Decharme, B., et al., 2016. Impacts of snow and organic soils parameterization on northern eurasian soil temperature profiles simulated by the isba land surface model. The Cryosphere, 10 (2), 853-877.

Delclaux, F., et al., 2008. Confronting models with observations for evaluating hydrological change in the lake chad basin, africa. In: XIIIth World Water Congress.

Dhar, O. and Rakhecha, P., 1981. The effect of elevation on monsoon rainfall distribution in the central himalayas. Monsoon Dynamics, 253-260.

Dickinson, R.E., 1984. Modelling evapotranspiration for three-dimensional global climate models. In: Climate Processes and Climate Sensitivity Geophysical Monograph, Hansen, J. E. Takahasi, T. (Eds.), Series 29, Washington.

Drusch, M., et al., 2012. Sentinel-2: Esa's optical high-resolution mission for gmes operational services. Remote Sensing of Environment, 120, 25-36. 
Dümenil, L. and Todini, E., 1992. A rainfall-runoff scheme for use in the hamburg climate model. In: Advances in theoretical hydrology: a tribute to james dooge. Elsevier Science Publishers BV, 129-157.

Dunne, T., 1983. Relation of field studies and modeling in the prediction of storm runoff. Journal of Hydrology, 65 (1-3), 25-48.

Eeckman, J., et al., 2017. Providing a non-deterministic representation of spatial variability of precipitation in the Everest region. Hydrology and Earth System Sciences Discussions, 2017, 1-21. Available from: http://www.hydrol-earth-syst-sci-discuss.net/hess-2017-137/.

Eeckman, J., 2017. Caractérisation des systèmes hydro-climatiques à l'échelle locale dans l’himalaya népalais. Thesis (PhD). Université Montpellier.

Gardelle, J., Berthier, E., and Arnaud, Y., 2012. Impact of resolution and radar penetration on glacier elevation changes computed from dem differencing. Journal of Glaciology, 58 (208), 419-422.

Gascoin, S., et al., 2015. A snow cover climatology for the pyrenees from modis snow products. Hydrology and Earth System Sciences.

Habets, F., et al., 1999. The $\{$ ISBA $\}$ surface scheme in a macroscale hydrological model applied to the hapex-mobilhy area: Part ii: Simulation of streamflows and annual water budget. Journal of Hydrology, 217 (12), 97 - 118. Available from: http://www.sciencedirect.com/science/article/pii/S0022169499000207.

Hall, D.K., et al., 2002. Modis snow-cover products. Remote Sensing of Environment, 83 (12), 181 - 194. The Moderate Resolution Imaging Spectroradiometer (MODIS): a new generation of Land Surface Monitoring, Available from: http://www.sciencedirect.com/science/article/pii/S0034425702000950.

Hargreaves, G.H. and Samani, Z.A., 1982. Estimating potential evapotranspiration. Journal of the Irrigation and Drainage Division, 108 (3), 225-230.

Heynen, M., et al., 2016. Air temperature variability in a high-elevation himalayan catchment. Annals of Glaciology, 57 (71), 212-222. 
Horton, R.E., 1933. The role of infiltration in the hydrologic cycle. Eos, Transactions American Geophysical Union, 14 (1), 446-460.

Immerzeel, W.W., Van Beek, L.P., and Bierkens, M.F., 2010. Climate change will affect the asian water towers. Science, 328 (5984), 1382-1385.

Jain, S.K., Goswami, A., and Saraf, A., 2008. Accuracy assessment of modis, noaa and irs data in snow cover mapping under himalayan conditions. International Journal of Remote Sensing, 29 (20), 5863-5878.

Knauf, D., 1980. Die Berechnung des Abflsses aus einer Schneedecke. Analyse und Berechnung oberirdischer Abflusse DVWK- Schriften, Bonn, Heft 46.

Kralisch, S. and Krause, P., 2006. JAMS A Framework for Natural Resource Model Development and Application. In: Proceedings of the International Environmental Software Society (IEMSS), Vermont, USA.

Kralisch, S., et al., 2007. Component based environmental modelling using the JAMS framework. In: MODSIM 2007 International Congress on Modelling and Simulation. 812-818. Peer reviewed.

Krause, P., 2001. Das hydrologische Modellsystem J2000: Beschreibung und Anwendung in groen Flueinzugsgebieten, Schriften des Forschungszentrum Jlich. Reihe Umwelt/Environment; Band 29.

Krause, P., 2002. Quantifying the Impact of Land Use Changes on the Water Balance of Large Catchments using the J2000 Model. Physics and Chemistry of the Earth, 27, 663-673.

Lang, T.J. and Barros, A.P., 2004. Winter storms in the central himalayas. Journal of Meteorological Society of Japan, 82 (3), 829-844.

Li, H., Haugen, J.E., and Xu, C., 2017. Precipitation Pattern in the Western Himalayas revealed by Four Datasets. Hydrology and Earth System Sciences Discussions, 2017, 1-19. Available from: http://www.hydrol-earth-syst-sci-discuss.net/hess-2017-296/.

Lutz, A., et al., 2014. Consistent increase in high asia's runoff due to increasing glacier melt and precipitation. Nature Climate Change, 4 (7), 587-592. 
774 Masson, V., et al., 2013. The SURFEXv7.2 land and ocean surface platform for coupled 775 or offline simulation of earth surface variables and fluxes. GEOSCIENTIFIC MODEL $776 \quad$ DEVELOPMENT, $6(4), 929-960$.

777 Masson, V., et al., 2003. A global database of land surface parameters at 1-km resolution in 778 meteorological and climate models. Journal of climate, 16 (9), 1261-1282.

Nepal, S., et al., 2014. Understanding the hydrological system dynamics of a glaciated alpine catchment in the Himalayan region using the J2000 hydrological model. Hydrological Processes, 28 (3), 1329-1344.

Nepal, S., et al., 2011. Understanding the impact of climate change in the glaciated alpine catchment of the Himalaya Region using the J2000 hydrological model. In: Proceedings of the Second International Symposium on Building Knowledge Bridges for a Sustainable Water Future, Panama, 2011. 55-60.

Nepal, S., 2012. Evaluating upstream-downstream linkages of hydrological dynamics in the himalayan region. Thesis (PhD). PhD Thesis. Friedrich Schiller University, Germany.

Nepal, S., et al., 2017a. Spatial gr4j conceptualization of the tamor glaciated alpine catchment in eastern nepal: evaluation of gr4jsg against streamflow and modis snow extent. Hydrological Processes, 31 (1), 51-68.

Nepal, S., et al., 2017b. Assessment of spatial transferability of process-based hydrological model parameters in two neighbouring catchments in the himalayan region. Hydrological Processes, 31 (16), 2812-2826.

Nepal, S., Flügel, W.A., and Shrestha, A.B., 2014. Upstream-downstream linkages of hydrological processes in the himalayan region. Ecological Processes, 3 (1), 1.

Noilhan, J. and Mahfouf, J.F., 1996. The isba land surface parameterisation scheme. Global and planetary Change, 13 (1), 145-159.

Noilhan, J. and Planton, S., 1989. A Simple Parameterization of Land Surface Processes for Meteorological Models. Monthly Weather Review, 117 (3), 536-549. Available from: http://dx.doi.org/10.1175/1520-0493(1989)117;0536:ASPOLS¿2.0.CO;2. 
Panday, P.K., et al., 2014. Application and evaluation of a snowmelt runoff model in the tamor river basin, eastern himalaya using a markov chain monte carlo (mcmc) data assimilation approach. Hydrological Processes, 28 (21), 5337-5353.

Pellicciotti, F., et al., 2012. Challenges and uncertainties in hydrological modeling of remote hindu kush-karakoram-himalayan (hkh) basins: suggestions for calibration strategies. Mountain Research and Development, 32 (1), 39-50.

Pokhrel, B.K., et al., 2014. Comparison of two snowmelt modelling approaches in the dudh koshi basin (eastern himalayas, nepal). Hydrological Sciences Journal, 59 (8), 1507-1518.

Racoviteanu, A.E., Armstrong, R., and Williams, M.W., 2013. Evaluation of an ice ablation model to estimate the contribution of melting glacier ice to annual discharge in the nepal himalaya. Water Resources Research, 49 (9), 5117-5133.

Salerno, F., et al., 2015. Weak precipitation, warm winters and springs impact glaciers of south slopes of mt. everest (central himalaya) in the last 2 decades (1994-2013). The Cryosphere, 9 (3), 1229-1247.

Savéan, M., 2014. Modélisation hydrologique distribuée et perception de la variabilité hydroclimatique par la population du bassin versant de la dudh koshi (népal). Thesis (PhD). Université de Montpellier 2.

Savéan, M., et al., 2015. Water budget on the Dudh Koshi River (Nepal): Uncertainties on precipitation. Journal of Hydrology. Available from: http://linkinghub.elsevier.com/retrieve/pii/S0022169415008082.

Sevruk, B., Ondrás, M., and Chvíla, B., 2009. The wmo precipitation measurement intercomparisons. Atmospheric Research, 92 (3), 376-380.

Shrestha, M., et al., 2011. Modeling the Spatial Distribution of Snow Cover in the Dudhkoshi Region of the Nepal Himalayas. Journal of Hydrometeorology, 13 (1), 204-222. Available from: https://doi.org/10.1175/JHM-D-10-05027.1.

Valery, A., Andreassian, V., and Perrin, C., 2010. Regionalization of precipitation and air temperature over high-altitude catchments learning from 
828 outliers. Hydrological Sciences Journal, 55 (6), 928-940. Available from: $829 \quad$ http://dx.doi.org/10.1080/02626667.2010.504676.

${ }_{830}$ Zhang, Y., Liu, S., and Ding, Y., 2007. Glacier meltwater and runoff modelling, keqicar baqi 831 glacier, southwestern tien shan, china. Journal of Glaciology, 53 (180), 91-98. 
Table 2: Summary of ISBA surface scheme and J2000 model structures, for precipitation phase distribution, interception, evapotranspiration, snow accumulation and melt, soil water, runoff components, groundwater and flow routing treatments.

ISBA

$\mathrm{J} 2000$

\section{Precipitation}

For both models: Precipitation is distributed between rain and snow according to the same threshold temperatures for both models.

\section{Interception}

For both models: Simple interception storage approach (Dickinson, 1984). The interception storage is computed according to the vegetation type defined by its Leaf Area Index (LAI) for rain and snow.

\section{Evapotranspiration (ET)}

ET results from the water and energy balance applied on bare soil, vegetation and snow-cover (Noilhan and Planton, 1989).

The potential ET is calculated by Hargreaves and Samani (1982) and is then checked against actual water storage in different landscape compartments (such as interception, soil water etc) to calculate actual ET.

\section{Snow accumulation and melt}

The ISBA-ES implementation (Boone and Etchevers, 2001; Decharme et al., 2016) provides a twelve-layer discretization of the snow pack. Mass and energy balances are computed for each layer, considering snow-melt and sublimation.
Potential melt from snow pack is estimated with energy input from temperature, rain and ground surface. Accumulation and melting can occur within a time step, controlled by separate accumulation or melt temperatures (Knauf, 1980).

\section{Soil water}

The diffusive approach (ISBA-DIF), (Boone Middle/large pore storage (MPS/LPS) partiet al., 2000; Decharme et al., 2011) uses a 14 layer discretization of the mixed-form richard's equation with vertcal soil water fluxes represented by Darcy's law.

tion. MPS refers to the field capacity, whereas LPS refers to the flowing water in the soil that generates subsurface runoff and percolation to groundwater reservoirs.

\section{Runoff components}

For both models: The notions of Dunne's flow (saturation excess runoff) and Horton's flow (infiltration excess runoff) are considered in the computation of surface runoff.

Dunne's and Horton's runoffs are controlled according to (Dümenil and Todini, 1992). The Dunne runoff for each grid cell depends on the fraction of the cell that is saturated.
Saturation excess runoff and infiltration excess runoff together provide overland flow (RD1) (Krause, 2001, 2002). When LPS is filled, the excess water is divided into sub-surface flow (RD2) and percolation to the groundwater reservoir.

\section{Groundwater}

Groundwater storage is reated by an additional conceptual module. Drainage at the bottom of the soil column is stored in a linear reservoir $\left(R_{d}\right)$, controlled by a calibrated residence time $\left(t_{d}\right)$.
The percolated water is distributed into two groundwater compartments, which produce interflow 2 (RG1) from shallow aquifers and baseflow (RG2) from deep aquifers.

\section{Routing}

Flow routing is treated by an additional conceptual module. The outflow is computed for each grid cell according to the average slope of the cell, weighted by a calibrated velocity coefficient.
The four different runoff components (RD1, RD2, RG1 and RG2) from each HRU are routed to the next connected HRU until it reaches a river network, using a simplified kinematic wave appiroach (Krause, 2001). 
Table 3: Summary of the spatial discretization methods used in ISBA and in J2000, for the Kharikhola and Tauche catchments.

\begin{tabular}{lccccc} 
& \multicolumn{2}{c}{ Kharikhola catchment } & \multicolumn{3}{c}{ Tauche catchment } \\
& ISBA & J2000 & ISBA & J2000 & \\
\hline Number of units & 69 cells & 346 HRUs & 28 cells & 132 HRUs & \\
Minimum size of units & 0.16 & 0.008 & 0.16 & 0.008 & $\mathrm{~km}^{2}$ \\
Minimum altitude & 2050 & 1997 & 4070 & 4021 & m.a.s.l. \\
Maximum altitude & 4326 & 4459 & 5600 & 5457 & m.a.s.l.
\end{tabular}

Table 4: Soil and vegetation characteristics of the nine classes defined in Kharikhola and Tauche catchments, respectively. \% KK and \% Tauche are the fraction of each class on Kharikhola and Tauche catchments. Sand and clay fractions (\% Sand and \% Clay, respectively), soil depth (SD), root depth (RD) and tree height (TH) are defined based on in situ measurements. The dynamic variables (e.g. the fraction of vegetation and Leaf Area Index) were found in the ECOCLIMAP1 classification (Masson et al., 2003) for representative ecosystems.

\begin{tabular}{|c|c|c|c|c|c|c|c|c|c|}
\hline ID & Class & $\% \mathrm{KK}$ & $\%$ Tauche & $\%$ Sand & \% Clay & $\begin{array}{c}\mathrm{TH} \\
\mathrm{m}\end{array}$ & $\begin{array}{l}\mathrm{SD} \\
\mathrm{m}\end{array}$ & $\begin{array}{c}\mathrm{RD} \\
\mathrm{m}\end{array}$ & $\begin{array}{c}\text { ECOCLIMAP1 } \\
\text { Cover }\end{array}$ \\
\hline 1 & Snow and ice & - & $0.7 \%$ & 0.00 & 0.00 & 0.0 & 0.00 & 0.00 & 6 \\
\hline 2 & Screes & $3.1 \%$ & $31.2 \%$ & 0.00 & 0.00 & 0.0 & 0.00 & 0.00 & 5 \\
\hline 3 & Steppe & $0.6 \%$ & $33.7 \%$ & 81.41 & 1.70 & 0.0 & 0.10 & 0.10 & 123 \\
\hline 4 & Shrubs & $7.4 \%$ & $34.4 \%$ & 70.60 & 1.55 & 0.0 & 0.35 & 0.27 & 86 \\
\hline 5 & Dry Forest & $9.7 \%$ & - & 72.86 & 1.00 & 12.0 & 0.20 & 0.20 & 27 \\
\hline 6 & Intermediary Forest & $45.7 \%$ & - & 84.97 & 1.01 & 27.5 & 0.42 & 0.40 & 27 \\
\hline 7 & Wet Forest & $20.6 \%$ & - & 70.12 & 1.00 & 6.8 & 1.04 & 0.50 & 27 \\
\hline 8 & Slope terraces & $11.2 \%$ & - & 70.89 & 1.38 & 5.6 & 0.56 & 0.26 & 171 \\
\hline 9 & Flat terraces & $1.4 \%$ & - & 67.01 & 1.69 & 2.5 & 1.267 & 0.20 & 171 \\
\hline
\end{tabular}


Table 5: Annual volumes for input variables (in millimetres per year): total precipitation, solid precipitation and for variables simulated by ISBA and J2000 models: actual evapotranspiration, discharge at the outlet, snow-melt contribution, snow pack storage variation and soil storage variation, for the 2014-2015 and 20152016 hydrological years, for the Kharikhola and Tauche catchments. Performance criteria ( Nash-Sutcliffe Efficiency NSE, relative bias Bias, , determination of coefficient $r^{2}, N S E$ for the square root of discharges $N S E_{\text {sqrt }}$ and $N S E$ computed for the high-flow period $N S E_{\text {high }}$ ), computed at the daily time scale are also provided.

\begin{tabular}{|c|c|c|c|c|c|c|c|c|}
\hline \multirow{3}{*}{$\begin{array}{l}\text { Observed discharges } \\
\text { Model }\end{array}$} & \multicolumn{4}{|c|}{ Kharikhola catchment } & \multicolumn{4}{|c|}{ Tauche catchment } \\
\hline & \multicolumn{2}{|c|}{$\begin{array}{c}2014-2015 \\
-\end{array}$} & \multicolumn{2}{|c|}{$\begin{array}{c}2015-2016 \\
1800\end{array}$} & \multicolumn{2}{|c|}{$\begin{array}{l}2014-2015 \\
\quad 440\end{array}$} & \multicolumn{2}{|c|}{$\begin{array}{c}2015-2016 \\
477\end{array}$} \\
\hline & ISBA & $\mathrm{J} 2000$ & ISBA & J2000 & ISBA & J2000 & ISBA & J2000 \\
\hline Total precipitation & 3034 & 3064 & 2256 & 2254 & 837 & 824 & 581 & 607 \\
\hline Solid precipitation & 42 & 36 & 27 & 26 & 403 & 281 & 245 & 148 \\
\hline Actual evapotranspiration & 579 & 548 & 622 & 555 & 292 & 372 & 285 & 363 \\
\hline Discharge at the outlet & 2346 & 2523 & 1631 & 1803 & 373 & 413 & 385 & 303 \\
\hline Snow-melt contribution & 53 & 50 & 27 & 21 & 336 & 276 & 309 & 199 \\
\hline Snow pack storage variation & 0 & 0 & 0 & 0 & -66 & -26 & 66 & 24 \\
\hline Soil storage variation & -41 & -16 & 33 & 15 & -8 & -7 & 7 & 6 \\
\hline$N S E$ & 0.5018 & 0.60453 & 0.9010 & 0.9158 & 0.8958 & 0.9194 & 0.6760 & 0.5172 \\
\hline Bias $_{r}$ & -45.7 & -37.1 & -9.7 & 0.04 & -11.7 & -2.8 & -19.5 & -39.0 \\
\hline$r^{2}$ & 0.8613 & 0.9049 & 0.9120 & 0.9327 & 0.9352 & 0.9453 & 0.7203 & 0.7944 \\
\hline$N S E_{\text {sqrt }}$ & 0.6645 & 0.6985 & 0.8733 & 0.9395 & 0.8553 & 0.8219 & 0.6888 & 0.6956 \\
\hline$N S E_{h i g h}$ & 0.0742 & 0.1512 & 0.7629 & 0.6640 & 0.7329 & 0.8400 & 0.0193 & -0.7239 \\
\hline
\end{tabular}

Table 6: Parametrisation of soil water content introduced in ISBA and in J2000. SAND and CLAY are respectively the average sand and clay fractions of the soil for each catchment. $w_{\text {sat }}$ is the water content of the soil column at saturation computed in ISBA. $\max M P S$ and $\max L P S$ are the maximal storage capacity in MPS and LPS reservoirs in J2000.

\begin{tabular}{lcc|ccc} 
Catchment & SAND & CLAY & $\begin{array}{c}w_{\text {sat }} \\
m m\end{array}$ & $\begin{array}{c}\max M P S \\
m m\end{array}$ & $\begin{array}{c}\max L P S \\
m m\end{array}$ \\
\hline Kharikhola & $79.9 \%$ & $1.1 \%$ & 207 & 98 & 100 \\
Tauche & $80.9 \%$ & $1.7 \%$ & 52 & 35 & 32
\end{tabular}

Table A.7: Results of the calibration of the HDSM routing module for the Kharikhola and the Tauche catchments, as well as the calibrated values for the Dudh Koshi basin by Savéan et al. (2015).

\begin{tabular}{lccc|ccc} 
& NSE & Bias $_{r}$ & $N S E_{\text {sqrt }}$ & $\begin{array}{c}T_{d} \\
\text { days }\end{array}$ & $\begin{array}{c}T_{s} \\
\text { hours }\end{array}$ & $\begin{array}{c}\text { cvel } \\
\mathrm{m} / \mathrm{s}\end{array}$ \\
\hline Kharikhola & 0.6906 & 0.2906 & 0.8051 & 39.5 & 0.75 & 0.0948 \\
Tauche & 0.742 & 0.0244 & 0.7775 & 48.1 & 1.77 & 0.0162 \\
Dudh Koshi, calibration & 0.73 & -0.5 & - & 12 & 1.5 & 1.7 \\
from (Savéan et al., 2015) & & & & & &
\end{tabular}

